\title{
4. The Empire Strikes Back: Mainstream media still matters
}

\author{
Wayne Errington
}

With so much attention being paid to the new forms of media transforming the public sphere, we can forget that most Australians follow election campaigns the old-fashioned way. According to the Australian Election Study (AES), those electors reporting that they follow election campaigns in the traditional media 'a good deal' are well down from the highs of the 1960s but they still dwarf those relying on the internet. In the 2013 election those who followed the election 'a good deal' on television amounted to 30 per cent, 15 per cent for radio and 17 per cent for newspapers. Close interest in all traditional media at election time has fallen consistently since 2007. While those claiming to have followed the election 'a good deal' has risen steadily, that group only reached 14 per cent in 2013 (McAllister and Cameron 2014). In an otherwise lacklustre 2013 campaign, the power and appropriate role of television, radio and newspapers became one of the major talking points. The News Corporation Australia (henceforth News Corp) press, in particular, was determined to show that old media still mattered, featuring partisan advocacy reminiscent of the 1975 post-Dismissal campaign against Labor. This chapter first reflects on the changing nature of media power, especially efforts by parties and commentators to set the campaign agenda, and then discusses the quality of the mass media coverage and the influence of the News Corp outlets in particular.

For those who love their politics, the 2013 election provided a cornucopia of media sources to take in every policy announcement, every debate or community forum, and every baby kissed. Political junkies could admire the professionalism of the likes of David Spears on Sky News; listen as the ABC bent over backwards to be fair to all points of view; watch (and read) Richo (Graham Richardson) indulge his dislike of Julia Gillard; or read (and watch) Andrew Bolt indulge his dislike of just about everybody. All this whilst monitoring our Twitter feeds and checking in on the many new forums for reporting and analysis online. On the 24-hour news channels, we witnessed the entirety of the press conference where journalists complained about having to quiz political leaders on policy documents they had been given only moments before. Later on the six o'clock commercial television news - watched, according to OzTams ratings, by more than ten times the audience of the 24-hour news channels - we received only a brief précis of the same policy announcement, followed by a quick analysis of the politics surrounding it, not the policy itself. 
Despite the rise of the internet and social media, television remains important enough to dominate the rhythms of an election campaign. Policy announcements, photo opportunities, speeches and fundraisers are timed for the desired coverage (or lack thereof) by the nightly television news. Digital technology has made news a relatively cheap way for television networks to fill their quotas for domestically produced content. Thus, we see early morning, breakfast, late morning, afternoon and late news able to cover breaking election stories, though rarely in any depth. However, it is the three million strong audiences on freeto-air evening television that provide the greatest exposure. The dominance of television amongst an increasingly diverse media provides the campaigns with both tactical and financial challenges. The parties need to engage voters for whom social media is the primary source of information, while attracting the attention of mainstream media consumers, inevitably through expensive television advertising. One audience expects a conversation about politics; the other would prefer to eat their dinner in peace. The result of the 2010 election was a reminder that Australian elections are sometimes decided by the slimmest of margins, so every vote counts and little is left to chance even by a party that finds itself streets ahead in the published opinion polls.

The 2013 federal election was the first election campaign in which the major Australian newspapers published not only printed editions but also operated news websites behind various kinds of paywall. This development represented a further polarisation of media consumption between the political news 'haves' and 'have-nots'. If you are reading this, you probably fall into the former category. You may hear about Alan Jones's indiscretions because they are reported on Media Watch, not because you find his 2GB breakfast show compelling. Arguably, the transformation of the media with its more refracted technologies and outlets, with different old and new platforms and divided between the 'haves' and 'have-nots', has encouraged the parties to change the ways they campaign and the messages they disseminate. Into this space we are also witnessing the arrival of much more partisan commentators, strident in their opinions and taking every opportunity to convince undecided voters of the merits of their preferred team or candidate.

\section{Assessing the power of the media}

The nature of the media's power remains elusive in spite of thousands of studies across a range of academic disciplines. ${ }^{1}$ Short-term media effects of most interest during an election campaign depend on the characteristics of the audience and

1 See Valkenberg and Peter (2013) for a recent review of media effects research, and Bennett and Iyengar (2010) for a taste of the debate. 
the context of the message or image. Education, partisanship, psychology and perceptions of the source of the message all influence the way voters process information (Scheufele and Tewksbury 2007: 16). Even so, journalism is one of the few professions ranking as low in public trust as politics. Yet, just as voters can distrust politicians in general but like a particular leader, most voters rely on a trusted media source for information about politics. Much of the partisanship in election coverage, particularly in the so-called 'quality press', is directed at audiences already committed to voting a particular way. Thus, The Australian and the Australian Financial Review have a disproportionately Liberal-voting audience, while the Sydney Morning Herald and Melbourne's Age now cater more to Labor and Green voters (Young 2011: 93). More problematic for the parties, and for understanding media effects on election results, are the tastes and attitudes of apathetic or swinging voters, many of whom do not closely follow the campaign.

\section{Agenda-setting and agenda-priming}

An increasingly media-savvy public is aware of the role of the media in setting and framing the agenda. Agenda-setting, though, is a complex process. It is not the exclusive domain of the gatekeepers inside media organisations, as political leaders, interest groups, voters and other actors also attempt to influence media content. Journalists enjoy revealing the attempts of political parties at media management but often have little choice but to succumb to that management when they are continually under pressure to break stories. Election campaigns are a combination of intense micro-management and inevitable unpredictability. The 2013 campaign provided a good example of the latter when New South Wales Premier Barry O'Farrell unexpectedly confronted Kevin Rudd on the Sydney Harbour foreshore over a hastily announced policy to move military establishments from Sydney to Brisbane.

Less well known than agenda-setting is agenda-priming, where voter preferences may depend on which issue (or issues) saturates the media during the campaign (Iyengar and Simon 2000: 157). The 2001 Australian federal election won by John Howard provides a good illustration of agenda-priming, when immigration, border control and national security issues which favoured the Coalition played a disproportionate role in the campaign. The extent to which late-deciding voters were affected by this coverage is difficult to discern exactly (Denemark et al. 2007: 94-5). In 2013, only 14 per cent of voters chose asylum seekers among the three issues most important to them in an Essential poll dominated by the economy, taxation and education. We can infer much about what private party polling in marginal seats reveals about swinging voters from the way leaders have responded to the asylum seeker issues in recent elections. With agendapriming in mind, even widely ridiculed policies such as buying up Indonesian 
fishing boats and comments from the candidate for Lindsay that refugees were causing traffic problems in western Sydney would have done the Coalition little harm. In 2013, the media, while usually indulging the agenda-setting tactics of the major party leaders, tended to return swiftly to some of the issues identified by voters as more important.

The out-going Labor Government responded to its precarious position in the published opinion polls by continually shifting emphasis, their supposed illdiscipline becoming a familiar campaign narrative. Rudd warned voters about the effect on the price of Vegemite that would be caused by the Coalition's failure to rule out changes to the GST. With little preparation or forethought, he launched policies promoting the development of northern Australia that senior Labor figures had ridiculed earlier in the year when the Coalition foreshadowed similar measures. There was no sustained argument from the Government about its achievements, and little sense of building on its television advertising accusing the Coalition of planning all manner of cuts to public services.

Economic management was the mainstay of the campaign (see Wanna's chapter). Journalists were determined to question the Opposition about the release of policy costings but were unable to divert the Coalition from their plans to detail their budget late in the campaign. By contrast, education and health were not covered by the mainstream media to the extent that polling indicated public interest in those issues. While bipartisanship on school education would be exposed as a mirage after the election, the parliamentary Labor Party had chosen to remove the leader who could speak with most credibility on education.

\section{Effect of declining media resources}

A further dimension of the power of the media during an election is the relative resources of the political parties, interest groups and media outlets. The financial problems of media companies have caused a decline in specialist reporters on issues such as defence, science and health, as well as the retrenchment of experienced journalists. This specialisation was historically the strength of quality newspapers. The campaign environment intensifies this problem with journalists expected to digest policy announcements at a moment's notice to file for news channels or websites. In response to declining revenue caused by online competition for both readers and advertisers, Australian newspapers have made hundreds of editorial positions redundant. While the role of News Corp during the campaign prompted discussion of that company's newspaper circulation (reaching two-thirds of the metropolitan population nationwide), the more important statistic was the 10 per cent decline in circulation across the board in the year to June 2013 (Audit Bureau of Circulation 2013). Radio and television have not been immune to these confronting forces but the unique 
role of newspapers in setting the agenda for electronic media gives the decline of newspapers greater political salience. It was not that long ago that scholars highlighted the great advantages that the 'PR State' (governments heavily investing in public relations, accumulating media advisors, setting up public sector media units and exploiting the use of government advertising), provides to governments compared to opposition parties and the fourth estate (see, for example, Ward 2007; Errington and van Onselen 2007). A neutral observer of the plights of the Rudd and Gillard Governments may have been unaware of this phenomenon. In both 2010 and 2013, the Labor caucus chose to give away the advantage of incumbency by electing new (and recycled) leaders.

After his resurrection in June 2013, Kevin Rudd made some rapid fire policy announcements about carbon pricing and the fringe benefits tax. Journalists were quick to point out that such announcements from a newly installed prime minister with no intention of recalling parliament prior to polling day had the authority of election promises more so than settled policy. In contrast, sending asylum seekers to Papua New Guinea could be achieved within existing legislation. One particularly cynical use of incumbency was the \$30 million government advertising campaign to promote the new policy (Lewis 2013). Notionally aimed at asylum seekers with the message 'If you come here by boat without a visa YOU WON'T BE SETTLED IN AUSTRALIA' (but initially carried only in English), the placement of the advertisements in domestic newspapers was met with well-deserved ridicule. A government that seemed to have learned from the experience of the Howard Government - that spending millions on government advertising only makes voters angry-unlearned the lesson just weeks before the 2013 election.

\section{The televised debates in the 2013 campaign}

Leader debates during the election campaign provide the two major parties with a more equal media footing than they otherwise have during the balance of the parliamentary term. The first leaders' debate in 2013 was almost universally derided for shallow, predictable questions from journalists and scripted responses from the leaders. As the headline on Sid Maher's (2013) analysis for The Australian put it, 'a night of waffle, scare campaigns and cost evasion'. Channel Nine's Laurie Oakes chimed in with some horse-race commentary, declaring Abbott the winner because his 'three-word slogans' amounted to 'sharper, clearer messages' even though he thought Rudd won on policy substance. The debate format chosen prevented sustained questioning of the leaders. Part of the waffle from both leaders came in their anodyne responses to a question on aged care that exposed the gap between the parties' policy ambitions and Treasury's lack of revenue. There was little follow-up on this 
issue in the rest of the campaign. Combined with the widespread view that a defeat for the Government seemed inevitable, the number of Australian Election Study respondents claiming to have watched a leaders' debate in 2013 was near an historic low at 32 per cent (McAllister and Cameron 2014).

Two subsequent debates - which have been rare in recent elections because incumbent prime ministers usually wish to minimise opportunities for their opponent to share a platform - were hosted by Sky News from RSL/Leagues mega clubs in Brisbane and Sydney. These were in format and content much livelier affairs. Questions from the general public, notionally swinging voters but inevitably featuring some partisans, were often pointed and some left the leaders floundering as they circled one another on the stage. In such a forum a leader cannot be seen to ignore a question from a voter and revert to talking points. They have to empathise with this audience in a way they need not with a panel of journalists. In one exchange, by refusing to join an audience member in condemning foreign investment in Australian farmland, Abbott looked prime ministerial compared to Rudd's populist posturing. This audience-centred format, which has been part of American presidential debates for decades, is likely to be used more often in Australian campaigns in the future. After the staid first debate, however, the main television networks had generally lost interest in what the leaders had to say - relegating the debates to their secondary digital channels, with about a quarter of the audience viewing them.

The news emerging from all the debates was predictably trivial-raising such items as whether Rudd flouted the rules by referring to speaking notes or whether Abbott was wise to tell the prime minister to shut up. In the way these things are usually appraised, Rudd's failure to deliver a 'knock-out blow' ensured that Abbott was considered the main beneficiary. Given the complete absence of wit among contemporary Australian political leaders - incapable of delivering a line like Ronald Reagan's 1984 promise not to use his opponent's youth and inexperience against him - just what a knock-out blow would look like in these debates is unclear. It was not only the debates, though, where reporting on the campaign showed a predilection towards the trivial.

\section{The trivial pursuits of reporters}

Julia Gillard hoped that nominating a September 2013 election date as early as January of that year would allow her Government to turn the nation's attention to government strengths and opposition weaknesses in policy. She was sorely disappointed, though, by her own party's capacity to make a spectacle of itself and by the press gallery's capacity to find alternatives to policy debate. There was some reflection among journalists, most notably ABC TV's Chris Uhlmann, 
about their own role in promoting leadership instability. Kerry-Anne Walsh (2013) indicted the entire press gallery for their role in 'stalking' Gillard. Former Minister for Finance and Deregulation Lindsay Tanner complained after the 2010 election that 'the media are retreating into an entertainment frame that has little tolerance for complex social and economic issues' (2011: 1). The trend towards trivialisation is clear enough, although the role that political leaders have played in enabling it bears some analysis.

Since those who avidly consume political media are less likely to change their vote than those who do their best to ignore coverage of politics, even much of the supposedly serious political programing can be more like entertainment than public affairs. Horse-race style coverage was common in the quality media in 2013, with every new poll making headline news. The traditional squabbling over Senate preference deals gained, in hindsight, greater than usual importance. Yet, as blogger and author Greg Jericho pointed out, for those who were interested, Election 2013 was 'policy heaven' yet 'fewer were consuming this detailed coverage' (2013). Substantial differences between the parties on broadband, taxation and parental leave were probed by journalists at press conferences with the party leaders. One effect of digital media is to create hours of extra air time that forces parties to offer up a wider range of spokespeople than during past campaigns which focused exclusively on the leaders. Journalist for The Australian and Sky News presenter, Peter van Onselen, complained via Twitter that an analysis piece of his comparing party policies received less feedback than anything he wrote about polling or party strategy during the campaign (van Onselen 2013).

Similarly, while the leaders of the two major parties dominated radio and television air time, the minor party candidates and independents also received a good deal of coverage. Some of this attention derived from the celebrity status of Clive Palmer and Julian Assange, whose profile on 60 Minutes did not outweigh the fractiousness of his Wikileaks Party. Journalists were enticed by free travel aboard Palmer's private jet although his business dealings generally received more attention than his policy platform.

There is a middle ground between the self-styled seriousness of interview programs and broadsheet newspapers, and the frippery of FM radio. Given the wide media choices available, it is important for politicians to communicate with those voters who do not pay much attention to formal news programing. Channel Ten's The Project provides a unique medium, aimed at a young adult audience and including plenty of political content, if not a lot of analytical depth. Joe Hockey and Kevin Rudd were regulars during the campaign — not so Tony Abbott. 
Abbott, like Rudd when he was Opposition Leader, had adopted a strategy of rarely engaging in lengthy interviews on $\mathrm{ABC}$ television and radio on programs such as $A M, 7.30$, Lateline and Insiders. This was partly a reaction to an interview with Kerry O'Brien in 2010 when Abbott questioned his own veracity. It may also suggest that Coalition strategists simply do not value these interviews as regular fare, preferring AM talkback radio to make their arguments. Nevertheless, Abbott handled such interviews perfectly well during the 2013 campaign and overall he was quizzed often enough on his policies during the campaign. The fact that he was disciplined in his responses, and didn't sway from his plan not to release policy costings until late in the campaign doesn't mean that the media didn't do its best to hold him to account. However, providing voters with a thorough understanding of what was at stake was another matter.

The costings debate raised interesting issues about the assumptions underlying budget forecasts and the fairest way to deal with the issue during an election campaign, but few outlets took the time to properly analyse the rival claims. Browbeaten by partisans into the safety of vacuous reporting of claim and counter-claim about the alleged lies of the other side, even ABC Television was of little help. For analysis they often turned to Labor and Liberal-leaning commentators who agreed the costings debate was in a terrible state. ABC Radio current affairs provided much better analysis than either the main ABC TV channel or the 24-hour news network through finance reporter Stephen Long.

Interestingly, the 2013 campaign saw the emergence of rival fact-checking organisations that were supposedly aimed at keeping the political parties and the media commentariat honest. Yet, there was not much evidence that these aspirations were achieved. Commentators barracking for one side or the other were always unlikely to be cowed by 'fact-checking'. The fact-checkers themselves tended to take an overly literal view of their brief and spend much of their time arguing over interpretations of key words. The ABC's Fact Check site wound up its thorough analysis of Labor's claims about the Coalition's supposed ' $\$ 70$ billion black hole' with this delightfully unreflective line: 'Only when the Coalition releases its spending and taxing plans in full will Labor be able to criticise its policies accurately' (ABC 2013). A greater endorsement of the Coalition's campaign strategy could not have been written. Nevertheless, this combination of media platforms signals a promising avenue for greater depth of coverage for those interested. ABC television news featured reports on Fact Check research. Channel Seven joined with Politifact for regular, if brief, reports on the major policy issues, in an effort to get beyond the claim and counterclaim that has become the staple of television news reporting. 


\section{Editorialising in newspaper reporting}

Kevin Rudd's return to the prime ministership posed an interesting dilemma for News Corp. Chairman Rupert Murdoch had signalled his distaste for the Gillard Government clearly enough - through his personal Twitter feed and the uniformly negative attitude of his Australian newspapers' editorials. In June, he tweeted: 'Australian public now totally disgusted with Labor Party wrecking country with its sordid intrigues. Now for a quick election' (Murdoch 2013). Murdoch dispatched legendary editor Col Allan to Australia from New York just before the campaign began. His task was reportedly to add some spark to the tabloids, something they didn't really seem to need.

Any doubts about whether Rudd's return would lead to a softer line were dispelled by the front page of Sydney's Daily Telegraph the day after Rudd announced the election date. The headline read: 'Finally you have the chance to ... KICK THIS MOB OUT' (5 August 2013). The lead-in to the banner in small print, implying that the paper was being guided by its readers in calling for a change of government, was a deft touch in demagoguery.

The Fairfax newspapers gave unusual prominence to criticism of their rival publisher's approach to the campaign. Their criticism was hard to justify since late in her prime ministership, The Age had delivered a similarly presumptuous direction to the Labor caucus to dump Gillard. As Walsh (2013) noted, Fairfax's Peter Hartcher played as important a role as any journalist in the destabilisation of Gillard. Fairfax's conservative commentator Paul Sheehan (2013) alleged that News Corp's loss of faith in Labor was motivated by the competitive challenge that the National Broadband Network (NBN) threatened to the one profitable part of News Corp Australia-Foxtel. While this seems a slim motive for such a vociferous campaign, it did go some way to explaining why News Corp appeared unconcerned about alienating the hundreds of thousands of loyal Labor voters who buy their newspapers. It would appear that many newspapers in the News Corp empire, such as The Australian, have been retained for influence rather than profit. That principle may now apply to the Australian tabloids as well.

Rudd took up the theme of News Corp's power on the campaign trail. Labor had long bristled at the lack of balance in News Corp's political coverage, culminating in the tabloids' response to the Government's 2013 proposals to give modest legislative force to newspaper content regulation. Comparisons of Communications Minister Stephen Conroy to various odious dictators captured the tone of News Corp's coverage of that issue. Rudd's indulgence in media criticism was emblematic of his total lack of campaign strategy. It also made him look like a whinger. 
Whether the tone of News Corp's editorial position influenced or followed the views of their readership over the course of six years of Labor Government is difficult to judge. A majority of News Corp papers supported a change of government in 2007, with some shifting back to the Coalition in 2010. More importantly, in terms of longer-term media effects on politics, the tone of dayto-day reporting on issues such as the home insulation scheme, school building projects and carbon pricing became particularly hostile throughout Gillard's term as prime minister. Roy Morgan Research found that the majority of News Corp tabloid readership, with the exception of the Hobart Mercury, supported the Coalition parties prior to the campaign (2013). The Australian, with its smaller audience but important agenda-setting role, amplified every complaint from the business sector into a national crisis.

In spite of the apparently unified senior editorial view, the News Corp tabloids varied in tone from city to city: more vociferous in Sydney and Brisbane, less so in Adelaide, Perth, Hobart and, at least during the campaign, in Melbourne. State-based election results lent weight to the idea that the tabloids had a limited effect, with the swings against Labor larger in Tasmania and Victoria than in New South Wales and Queensland. Yet those results also reflected the fact that the southern states swung towards Labor in 2010, and so contained more swinging voters yet to wield their baseball bats. Still, the voters of the Brisbane seat of Forde seemed to agree with the front-page banner of the Courier-Mail exclaiming: 'Send in the Clown', prompted by Kevin Rudd's announcement that Peter Beattie would be the candidate for the Coalition-held seat (Wardill 2013).

Analysis in the News Corp tabloids followed the pattern set by the front page editorialising. While we learned some detail about Abbott's home life in 'Tough guy Tony Abbott's secret is out', featuring a photograph of the Opposition Leader training with an army regiment in Darwin, the Daily Telegraph also agonised over the question of 'Kevin Rudd: Hero or Psychopath?' With admirable objectivity, the Telegraph concluded that the prime minister's mental state was 'an open-ended question' (Carswell 2013). Prior to the election, the Telegraph featured a series entitled 'Wreck-it Rudd', playing on a recent children's movie title, reminding voters of Rudd's record on asylum seekers, home insulation and other policy areas during his first stint as prime minister, as well as his proposed changes to the fringe benefits tax. Even The Australian could not keep up the pretence of former Coalition staffer Chris Kenny providing objective analysis in a column entitled 'Picking the Spin'. This feature was put on the back-burner after the first week of the campaign.

Kevin Rudd was not News Corp's only target. Having the temerity to start his own party in competition with the Coalition put Clive Palmer close to the top of The Australian's ever-growing list of enemies. Hedley Thomas (2013) pointed out that billionaire 'Professor' Palmer was neither a billionaire nor a professor. The 
change of tone in the paper's coverage of Palmer after the Queenslander quit the Liberal National Party at the end of 2011 -including prominent and exhaustive coverage of the magnate's legal battles - was clear enough. When Wayne Swan attacked Palmer, along with mining magnate and Australia's richest woman Gina Reinhardt, in 2011 for supporting policies that increase inequality, The Australian cried class warfare.

Reflecting the diversity of their readership, the News Corp tabloids stopped some way short of blatant one-sidedness. All the News Corp Sunday tabloids carried a compassionate feature about a baby lost when a boat carrying asylum seekers was struck by a storm in Indonesian waters. Sydney's Daily Telegraph joined in the fun of the hunt for Jaymes Diaz, the Liberal candidate for Greenway in Sydney's west who early in the campaign gained worldwide attention for his heroic failure to nominate more than one of the six points of the Coalition's asylum seeker policy in a television interview. He was thereafter hardly spotted until polling day, encouraging a competition among media outlets to spot him campaigning - one of a number of Coalition candidates under instructions from campaign headquarters to refuse interview requests from national media outlets. Some of the best policy analysis of the campaign came from the national economics correspondent for News Corp, Jessica Irvine, who lashed both major parties for their failure to face up to the long-term constraints on fiscal policy.

\section{Conclusion}

Old media showed it still counted in its coverage of the 2013 campaign. These traditional media outlets are now successfully integrating with new media and social media to provide excellent coverage of election campaigns - both in real-time coverage of events and in policy analysis - for that minority of the electorate sufficiently interested in intensive coverage. While the power of News Corp was a point of interest in the campaign, it is their ongoing reporting over the parliamentary cycle, rather than their attention-grabbing headlines, which frames and influences the political agenda. Recent changes in media technology are further polarising the Australian electorate between those maximising these opportunities and those who are exposed only to occasional messages about politics, often from a partisan or ephemeral source. In a nation where voting is compulsory, these trends are worthy of further reflection. 


\section{References}

Australian Broadcasting Corporation (ABC). 2013. 'Kevin Rudd's \$70 billion black hole claim not credible'. 14 August, viewed 7 January 2014: <www. abc.net.au/news/2013-08-14/kevin-rudd-70-billion-black-hole-claim-notcredible/4871852>.

Bennett, W Lance and Iyengar, Shanto. 2010. 'The Shifting Foundations of Political Communication: Responding to a defense of the media effects paradigm'. Journal of Communication 60(1): 35-9.

Carswell, Andrew. 2013. 'Kevin Rudd: hero or psychopath?' Daily Telegraph, 10 August, viewed 7 January 2014: <www.dailytelegraph.com.au/news/nsw/ kevin-rudd-hero-or-psychopath/story-fni0cx12-1226694584192>.

Denemark, David, Ward, Ian and Bean, Clive. 2007. 'Election Campaigns and Television News Coverage: The case of the 2001 Australian election'. Australian Journal of Political Science 42(1): 89-109.

Errington, Wayne and van Onselen, Peter. 2007. 'The Democratic State as a Campaign Tool: The permanent campaign in Australia'. Journal of Commonwealth and Comparative Politics 45(1): 78-91.

Iyengar, Shanto and Simon, Adam. 2000. 'New Perspectives and Evidence on Political Communication and Campaign Effects'. Annual Review of Psychology 51: 149-69.

Jericho, Greg. 2013. 'In (qualified) praise of the press gallery'. The Drum, 11 September, viewed 11 September 2013: <www.abc.net.au/news/2013-09-11/ jericho-in-qualified-praise-of-the-press-gallery/4948676>.

Lewis, Steve. 2013. 'Kevin Rudd's ads promoting PNG deal to cost taxpayers \$30m'. News.com.au, 11 August, viewed 11 August 2013: <www.news.com. $\mathrm{au} /$ national/kevin-rudd8217s-ads-promoting-png-deal-to-cost-taxpayers30m/story-fnho52ip-1226695091761>.

Maher, Sid. 2013. 'A night of waffle, scare campaigns and cost evasion'. The Australian, 12 August, viewed 27 February 2014: <www.theaustralian.com. au/national-affairs/election-2013/a-night-of-waffle-scare-campaigns-andcost-evasion/story-fn9qr68y-1226695199954>.

McAllister, Ian and Cameron, Sarah. 2014. Trends in Australian Political Opinion: Results From the Australian Election Study 1987-2013. Canberra: The Australian National University. 
Murdoch, Rupert. 2013. 'Australian public now totally disgusted with Labor Party wrecking country with its sordid intrigues. Now for a quick election.' 27 June, Twitter post: @rupertmurdoch.

Roy Morgan Research. 2013. 'The Political Profiles of Newspapers'. Roy Morgan Profiles, 28 August.

Scheufele, Dietram and Tewksbury, David. 2007. 'Framing, Agenda-Setting, and Priming: The evolution of three media effects models'. Journal of Political Communication (57): 9-20.

Sheehan, Paul. 2013. 'A 21st century fox playing chicken'. The Sydney Morning Herald, 5 August, viewed 5 August 2013: <www.smh.com.au/comment/a21st-century-fox-playing-chicken-20130804-2r7ir.html $>$.

Tanner, Lindsay. 2011. Sideshow: Dumbing down democracy. Melbourne: Scribe.

Thomas, Hedley. 2013. 'Why we need to worry about the real Clive Palmer'. The Australian, 5 September, viewed 5 September 2013: <www.theaustralian. com.au/news/investigations/why-we-need-to-worry-about-the-real-clivepalmer/story-fn6tcxar-1226710922127>.

Valkenburg, Patti and Peter, Jochen. 2013. 'Five Challenges for the Future of Media Effects Research'. International Journal of Communication 7: 197-215.

van Onselen, Peter. 2013. 'For all the complaining the media don't focus on policy, my feature (comparing policies) today had less feedback than any other I've done!' 2 September, Twitter post: @vanonselenp.

Walsh, Kerry-Anne. 2013. The Stalking of Julia Gillard: How the media and Team Rudd contrived to bring down the Prime Minister. Sydney: Allen \& Unwin.

Ward, Ian. 2007. 'Mapping the Australian PR State'. In Sally Young (ed.), Government Communication in Australia, Melbourne: Cambridge University Press.

Wardill, Steven. 2013. 'Prime Minister Kevin Rudd begs spinner Peter Beattie to help rescue Labor'. Courier-Mail, 9 August, viewed 15 January: <www. couriermail.com.au/news/queensland/prime-minister-kevin-rudd-begsspinner-peter-beattie-to-help-rescue-labor/story-fnihsrf2-1226693889409>.

Young, Sally. 2011. How Australia Decides: Election reporting and the media. Melbourne: Cambridge University Press. 
This text taken from Abbott's Gambit: The 2013 Australian Federal Election, edited by Carol Johnson and John Wanna, published 2015 by ANU Press, The Australian National University, Canberra, Australia. 